\title{
Estimation of Age at Death by Femoral Osteon Remodeling: Application of THOMPSON's Core Technique to Modern Japanese
}

\author{
Shuichiro NARASAKI \\ Department of Anthropology, Faculty of Science, \\ The University of Tokyo and Laboratoire d'Anthropologie, \\ Faculté des Sciences, Université de Bordeaux I
}

\begin{abstract}
THOMPSON's core technique for estimation of age at death was applied to 52 modern Japanese cadavers. Bone cores with $4 \mathrm{~mm}$ in diameter were removed from anterior midshaft of left femur of 28 males and 24 females ranged in age from 43 to 98 years. Variables used in this study include cortical thickness, core weight, total secondary osteon number, mean secondary osteon area, secondary osteon area standard deviation, mean secondary osteon perimeter, secondary osteon perimeter standard deviation, and total secondary osteon area. Multiple regression formula was calculated in both sexes. Multiple correlation coefficients and standard errors were 0.581 and 9.28 in males, 0.748 and 9.95 in females, respectively.
\end{abstract}

Keywords Estimation of Age at Death, Core Technique, Secondary Osteon, Femur, Japanese

\section{Introduction}

Application of histology to the study of bone and teeth extends back into the 19th century (UBELAKER, 1978). However, until recently, the microscopic age estimation technique was not used in the field of physical anthropology and forensic anthropology. This technique uses internal cortical bone remodeling process as indicator of age-related change (ENLOW, 1963; FROST, 1963; JOWSEY, 1960) and it could extend the age range over 50 years which is difficult for the conventional techniques.

KERLEY (1965, 1969, 1970) developed an aging method using a sample of 126 undecalcified sections of femur, tibia, and fibula. Later, KERLEY found some mistakes of his 1965 paper and produced new regression equations (KERLEY and UBELAKER, 1978). However, this correction was still criticized by STOUT and GEHLERT (1982). ZHU (1983) applied KERLEY's method to 35 Chinese femora and achieved better results than KERLEY's method. However, ZHU did not use KERLEY's corrected regression equations, therefore the results might have been affected. Using a sample of 20 femora, AHLQVIST and DAMSTEN (1969) modified the KERLEY's method and changed the location of the field since one of KERLEY's visual fields of the femur falls directly upon the linea aspera, an area claimed 
to have less age-related osteons. Their method was used by UBELAKER (1974) to 150 archaeologically excavated skeletal samples from two ossuaries of the Juhle site, Charles County, Maryland. Also, their method was checked by UYTTERSCHAUT (1985) using a sample of 20 femora and she produced new regression equation for tibia. BOUVIER and UBELAKER (1977) compared the KERLEY's method and AHLQVIST and DAMSTEN's method and found that KERLEY's method produces more accurate age estimates. However, these two methods have disadvantage in requiring complete cross section of the bone. SINGH and GUNBERG (1970)'s method takes $1 \mathrm{~cm}$ diameter bone sample and they achieved the 2.55 years standard error which is the lowest among the known methods. These three methods described above paid no attention
L

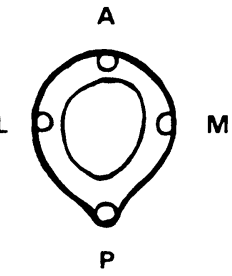

KER LEY

$(1965)$
L

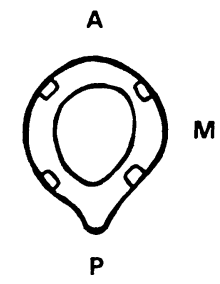

AHLOVIST $\&$

(1969)

A

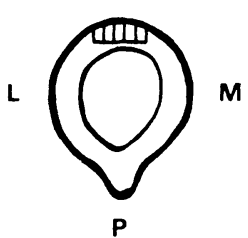

$S$ I NGH

G U N $\stackrel{8}{\text { B ER G }}$

$(1970)$

Fig. 1. Locations of the fields examined for microscopic structure to estimate the age at death in four methods. $\mathrm{A}=$ Anterior. $\mathrm{P}=$ Posterior. $\mathrm{M}=$ Medial. $\mathrm{L}=$ Lateral. to the sex and the side of the bone. The final method was introduced by THOMPSON in 1979 and this "Core Technique" takes bone sample only $4 \mathrm{~mm}$ in diameter leaving the bones intact (Fig. 1). This method was developed at the Laboratory of Biological Anthropology, Dept. of Biobehavioral Sciences (presently Dept. of Ecology and Evolutionary Biology), Univ. of Connecticut. THOMPSON used large sample to establish the regression formula for sex and sides of the bones separately (Table 1).

THOMPSON's method was applied to autopsy series (THOMPSON, 1981; THOMPSON and GALVIN, 1983), mummies (THOMPSON and COWEN, 1984; THOMPSON and LAUGHLIN, 1985), archaeologically excavated Eskimo skeletons (THOMPSON and GUNNESS-HEY, 1981; THOMPSON et al., 1981, 1982, 1982-1984), and Neandertal skeletons (THOMPSON and TRINKAUS, 1980; TRINKAUS and THOMPSON, 1987).

Although his method seems to work well in Caucasian white and black populations, it was noticed that in Eskimo population the estimation of age at death was tended to be overaged (THOMPSON and GuNNESS-HEY, 1981). Age estimation error was also reported by UBELAKER (1986) when he applied the KERLEY's method to cemeteries skeletal samples from Santo Domingo, Dominican Republic. They argue that population-specific equations must be established.

The purpose of this paper is to test the reliability of THOMPSON's method by modern Japanese sample and to establish the Japanese population equations.

\section{Materials and Methods}

The sample used in this study was obtained from 52 cadavers ( 28 males and 24 females) from anatomy dissection room of which 22 (11 males and 11 females) derived from Dept. of Anatomy, 
Table 1. Sample size and distributional data by study and bone

\begin{tabular}{|c|c|c|c|c|c|c|c|}
\hline & Study* & Bone** & $\mathrm{N}$ & Sex & $\begin{array}{l}\text { Mean age } \\
\text { (years) }\end{array}$ & $\begin{array}{l}\text { Range } \\
\text { (years) }\end{array}$ & S.E. \\
\hline I. & $\begin{array}{l}\text { KERLEY } \\
(1965)\end{array}$ & Femur & 67 & Mix & 41.55 & $0-95$ & 9.39 \\
\hline I-1. & $\begin{array}{l}\text { ZHU } \\
(1983)\end{array}$ & Femur & 35 & Mix & 39.14 & $5-86$ & $1.51-13.80$ \\
\hline II. & $\begin{array}{l}\text { AHLQVIST and } \\
\text { DAMSTEN } \\
(1969)\end{array}$ & Femur & 20 & Mix & 55.45 & $4-89$ & 6.71 \\
\hline II-1. & $\begin{array}{l}\text { UYTTERSCHAUT } \\
\text { (1985) }\end{array}$ & Femur & 20 & Mix & 53.70 & $17-92$ & 6.51 \\
\hline III. & $\begin{array}{l}\text { SINGH and } \\
\text { GUNBERG } \\
(1970)\end{array}$ & Femur & 33 & M & 62.33 & $40-80$ & $2.55-3.83$ \\
\hline IV. & $\begin{array}{l}\text { THOMPSON } \\
\text { (1979) }\end{array}$ & $\begin{array}{l}\text { L. Femur } \\
\text { NPL. Femur } \\
\text { L. Femur } \\
\text { NPL. Femur } \\
\text { L. Femur } \\
\text { NPL. Femur } \\
\text { R. Femur } \\
\text { NPR. Femur } \\
\text { R. Femur } \\
\text { NPR. Femur } \\
\text { R. Femur } \\
\text { NPR. Femur }\end{array}$ & $\begin{array}{r}91 \\
68 \\
53 \\
41 \\
38 \\
27 \\
113 \\
90 \\
63 \\
54 \\
50 \\
36\end{array}$ & $\begin{array}{l}\text { Mix } \\
\text { Mix } \\
\text { M } \\
\text { M } \\
\text { F } \\
\text { F } \\
\text { Mix } \\
\text { Mix } \\
\text { M } \\
\text { M } \\
\text { F } \\
\text { F }\end{array}$ & $\begin{array}{l}69.47 \\
70.68 \\
69.94 \\
71.49 \\
68.82 \\
69.44 \\
72.10 \\
73.20 \\
72.67 \\
73.93 \\
71.38 \\
72.11\end{array}$ & $\begin{array}{l}30-97 \\
30-97 \\
30-97 \\
30-97 \\
43-94 \\
43-94 \\
30-97 \\
30-97 \\
30-97 \\
30-97 \\
43-94 \\
43-94\end{array}$ & $\begin{array}{l}7.07-8.65 \\
6.99-8.53 \\
6.85-8.22 \\
6.67-7.69 \\
7.27-9.37 \\
7.24-9.70 \\
7.37-7.88 \\
7.33-7.93 \\
6.41-7.07 \\
6.41-7.15 \\
7.22-8.48 \\
7.47-8.18\end{array}$ \\
\hline IV-1. & $\begin{array}{l}\text { NARASAKI } \\
\text { (present study) }\end{array}$ & $\begin{array}{l}\text { L. Femur } \\
\text { L. Femur }\end{array}$ & $\begin{array}{l}28 \\
24\end{array}$ & $\begin{array}{l}M \\
F\end{array}$ & $\begin{array}{l}78.96 \\
75.71\end{array}$ & $\begin{array}{l}54-98 \\
43-94\end{array}$ & $\begin{array}{l}9.28 \\
9.95\end{array}$ \\
\hline
\end{tabular}

* I, II, III, and IV are original methods. I-1, II-1, and IV-1 are followers of original methods. KERLEY (1965), UYTTERSHAUT (1985), SINGH and GUNBERG (1970), and THOMPSON (1979) studied other bones. However, only the results of the femur are listed here.

**: R: right. L: left. NP: nonpathological. M: male. F: female. Mix: mixed. "Bone" are mixed side otherwise stated.

Faculty of Medicine, Univ. of Tokyo, and 30 (17 males and 13 females) from Dept. of Anatomy, School of Medicine, Yokohama City Univ. The sample was well documented as to sex, age at death, and primary cause of death. Males ranged in age from 54 to 98 years with a mean of 78.96 years (S.D. $=11.20$ ) and females from 43 to 94 years with a mean of 75.71 years $(S . D .=14.67)$
(Table 2).

The core technique was used to obtain the bone sample (THOMPSON, 1979). The cortical bone cores were removed from the anterior midshaft of the femur by a high-speed Dremel drill (Dremel, Model 33). The specially designed corers were mounted to the drill and cortical bone cores with $4 \mathrm{~mm}$ in diameter were removed. A total of 
Table 2. Age distribution of materials

\begin{tabular}{lcc}
\hline Age & Males & Females \\
\hline $40-49$ & 0 & 3 \\
$50-59$ & 2 & 0 \\
$60-69$ & 4 & 4 \\
$70-79$ & 6 & 4 \\
$80-89$ & 11 & 10 \\
$90-99$ & 5 & 3 \\
\hline Total & 28 & 24 \\
Mean age & 78.96 & 75.71 \\
S.D. & 11.20 & 14.67 \\
\hline
\end{tabular}

52 bone cores were removed from left femur of the cadavers, and microscopically analyzed.

After each bone core was removed from the cadaver, the core sample was placed in a 1 dram vial container with $10 \%$ basic formalin. The core was sectioned by Buehler Isomet Low-speed Saw (Model 11-1180) with diamond blade. Water was used for the blade lubricant. A section ca. 80 to $90 \mu \mathrm{m}$ in thickness was removed from each core in a plane that was transverse to the longitudinal axis of the long bone and hand griding was done on 800 grit Carbimet paper. The prepared bone sections were then mounted on microscope slides with synthetic mounting medium.

Cortical bone variables assessed in this study include, cortical thickness [CT], core weight [CW], total secondary osteon number [TOST], mean secondary osteon area [MOSTA], secondary osteon area standard deviation [MOSTASD], mean secondary osteon perimeter [MOSTP], secondary osteon perimeter standard deviation [MOSTPSD], and total secondary osteon area [AREA]. Among these 8 variables, 6 variables such as CT, CW, TOST, MOSTA, MOSTP, and AREA were included in THOMPSON's 19 variables (THOMPSON, 1979). His variables include, (1): cortical thickness, (2): core weight, (3): cortical bone density, (4): mineral content, (5): mineral index, (6): aggregate osteon lamellae area, (7): aggregate Haversian canal area, (8): osteon area, (9): secondary osteon number, (10): Haversian canal number, (11): individual osteon lamellae area, (12): individual Haversian canal area, (13): aggregate osteon perimeter, (14): aggregate Haversian canal perimeter, (15): individual osteon perimeter, (16): individual Haversian canal perimeter, (17): 7/6, (18): $14 / 13$, and (19): $16 / 15$. However, he found that on the left femur, osteon area, cortical thickness, individual osteon perimeter, aggregate osteon perimeter, and secondary osteon number, were significant variables in the estimation of age at death. Therefore, 6 variables described before were selected from his original study. Also MOSTASD and MOSTPSD were newly introduced in this study in order to improve the accuracy of age estimation. It is known that individual osteon size decreases with advancing age and as a result, the number of the osteons increases with advancing age (ARNOLD et al., 1966; CurReY, 1964, SingH and GunBERG, 1970; THOMPSON, 1979). Theoretically, the standard deviation of the area and perimeter of secondary osteons also decrease with advancing age. This tendency was observed in this study.

Cortical thickness was measured from the periosteal surface to endosteal surface by standard dial caliper to the nearest $0.1 \mathrm{~mm}$. Core weight was determined by Mettler Analytical Balance (Model A30) to the nearest $0.001 \mathrm{~g}$.

Microscopic analysis of the bone sections was processed by semi-automatic image analysis system consisting of a microprojector, a Numonics 1224 image analyzer and an IBM 370 computer. A microscope slide containing a bone section is placed in the microprojector and the image of the bone section is projected onto a white paper which has square line. Each side of the square is calculated being precisely $1 \mathrm{~mm}$. The periosteal border of the bone section was microscopically analyzed. Three fields were analyzed for each section. Firstly, numbers of secondary osteons were counted and marked on 
the grid, then traced with the drawing arm of image analyzer. The Numonics calculator was equipped with a simultaneous area and length (perimeter) software package that determined area and perimeter from a single trace of the secondary osteon.

\section{Results and Discussion}

The summary of histological analysis (Table
3) and the linear correlation among nine variables for males (Table 4) and females (Table 5) are given. In general, the male series did not correlate well with age. However, in female series, cortical thickness $[C T](p<0.001)$, cortical weight [CW] $(\mathrm{p}<0.001)$, mean secondary osteon area [MOSTA] $(p<0.05)$, mean secondary osteon area standard deviation [MOSTASD] $(\mathrm{p}<0.1)$, mean secondary osteon perimeter [MOSTP]

Table 3. Summary of histological analysis

\begin{tabular}{|c|c|c|c|c|c|c|}
\hline \multirow{2}{*}{ Variable* } & \multicolumn{3}{|c|}{ Males } & \multicolumn{3}{|c|}{ Females } \\
\hline & Mean & S.D. & Range & Mean & S.D. & Range \\
\hline $\mathrm{CT}(\mathrm{mm})$ & 4.6 & 0.78 & $3.0-6.6$ & 3.3 & 1.29 & $1.0-5.5$ \\
\hline CW (g) & 0.109 & 0.020 & $0.064-0.160$ & 0.076 & 0.031 & $0.018-0.126$ \\
\hline TOST $\left(\# / \mathrm{mm}^{2}\right)$ & 17.0 & 4.93 & $7.70-29.00$ & 14.8 & 4.06 & $9.3-24.0$ \\
\hline MOSTA $\left(\mathrm{mm}^{2}\right)$ & 0.023 & 0.0045 & $0.014-0.034$ & 0.022 & 0.0067 & $0.014-0.042$ \\
\hline MOSTASD & 0.013 & 0.0043 & $0.0085-0.026$ & 0.013 & 0.0050 & $0.008-0.030$ \\
\hline MOSTP (mm) & 0.556 & 0.059 & $0.441-0.682$ & 0.546 & 0.076 & $0.428-0.734$ \\
\hline MOSTPSD & 0.172 & 0.039 & $0.110-0.283$ & 0.169 & 0.040 & $0.119-0.296$ \\
\hline $\operatorname{AREA}\left(\mathrm{mm}^{2}\right)$ & 0.371 & 0.0714 & $0.222-0.478$ & 0.313 & 0.0687 & $0.212-0.476$ \\
\hline
\end{tabular}

* CT: cortical thickness. CW: cortical weight. TOST: total secondary osteon number. MOSTA: mean secondary osteon area. MOSTASD: mean secondary osteon area standard deviation. MOSTP: mean secondary osteon perimeter. MOSTPSD: mean secondary osteon perimeter standard deviation. AREA: total secondary osteon area.

Table 4. Linear correlation among 9 variables for males

\begin{tabular}{|c|c|c|c|c|c|c|c|c|}
\hline & $\mathrm{AGE}$ & CT & $\mathrm{CW}$ & TOST & MOSTA & MOSTASD & MOSTP & MOSTPSD \\
\hline $\mathrm{CT}$ & -0.186 & & & & & & & \\
\hline $\mathrm{CW}$ & -0.235 & 0.921 & & & & & & \\
\hline TOST & 0.004 & 0.288 & 0.337 & & & & & \\
\hline MOSTA & -0.123 & -0.210 & -0.209 & -0.761 & & & & \\
\hline MOSTASD & -0.275 & -0.049 & -0.059 & -0.482 & 0.724 & & & \\
\hline MOSTP & -0.123 & -0.244 & -0.230 & -0.789 & 0.964 & 0.549 & & \\
\hline MOSTPSD & -0.308 & -0.043 & -0.037 & -0.506 & 0.654 & 0.965 & 0.495 & \\
\hline AREA & -0.171 & 0.221 & 0.323 & 0.715 & -0.143 & 0.034 & -0.223 & -0.076 \\
\hline
\end{tabular}


Table 5. Linear correlation among 9 variables for females

\begin{tabular}{lrrrrrrrr}
\hline & AGE & CT & CW & TOST & MOSTA & MOSTASD & MOSTP MOSTPSD \\
CT & -0.647 & & & & & & & \\
CW & -0.648 & 0.957 & & & & & & \\
TOST & 0.279 & -0.107 & 0.008 & & & & & \\
MOSTA & -0.480 & 0.549 & 0.483 & -0.595 & & & & \\
MOSTASD & -0.387 & 0.497 & 0.419 & -0.504 & 0.895 & & & \\
MOSTP & -0.488 & 0.532 & 0.470 & -0.662 & 0.978 & 0.827 & & \\
MOSTPSD & -0.370 & 0.463 & 0.397 & -0.438 & 0.754 & 0.942 & 0.702 & \\
AREA & -0.264 & 0.540 & 0.611 & 0.406 & 0.473 & 0.441 & 0.388 & 0.378 \\
\hline
\end{tabular}

( $p<0.05$ ), and mean secondary osteon perimeter standard deviation [MOSTPSD] $(p<0.1)$ correlate well with age. In the case of cortical thickness and cortical weight, female series shows high correlations with age. This results confirm the cortical bone loss in female after menopause (MAZESS, 1982).

Using the eight variables, multiple regression equations were calculated separately for males and females (Table 6). In both sexes, highest multiple correlation coefficients were obtained when all eight variables were used. The multiple correlation coefficients and standard errors are 0.581 and 9.28 in males and 0.748 and 9.95 in females, respectively. Comparisons of known age and estimated age for males (Table 7) and females (Table 8) are given. A mean difference of 7.45 years was obtained for males and 7.23 years for females.

The accuracy of this regression formula was not so high compared with other methods (Table 1). However, standard error of this study is closer

Table 6. Regression coefficients and standard error for males and females

\begin{tabular}{|c|c|c|c|c|}
\hline \multirow[b]{2}{*}{ Variable } & \multicolumn{2}{|c|}{ Males } & \multicolumn{2}{|c|}{ Females } \\
\hline & Coefficient & S.D. & Coefficient & S.D. \\
\hline Constant & 257.77 & 86.77 & 67.18 & 96.78 \\
\hline $\mathrm{CT}$ & -2.017 & 7.669 & 2.194 & 7.782 \\
\hline $\mathrm{CW}$ & -14.6 & 306.4 & -407.0 & 332.6 \\
\hline TOST & -0.017 & 2.066 & -1.875 & 3.822 \\
\hline MOSTA & 7754.0 & 3944.0 & -7162.0 & 5360.0 \\
\hline MOSTASD & -1670.0 & 3163.0 & 6103.0 & 4628.0 \\
\hline MOSTP & -509.7 & 254.6 & 278.5 & 287.6 \\
\hline MOSTPSD & -125.9 & 274.5 & -427.3 & 342.8 \\
\hline AREA & -44.89 & 98.15 & 191.2 & 214.5 \\
\hline $\begin{array}{l}\text { Multiple } \\
\text { corr. coeff. }\end{array}$ & \multicolumn{2}{|c|}{0.581} & \multicolumn{2}{|c|}{0.748} \\
\hline Standard error & \multicolumn{2}{|c|}{9.28} & \multicolumn{2}{|c|}{9.95} \\
\hline
\end{tabular}


Table 7. Comparisons of known age and histologically estimated age for males

\begin{tabular}{lccr}
\hline IDNO & $\begin{array}{c}\text { Known age } \\
\text { (years) }\end{array}$ & $\begin{array}{c}\text { Estimated age } \\
\text { (years) }\end{array}$ & $\begin{array}{r}\text { Difference } \\
\text { (years) }\end{array}$ \\
\hline M01 & 54.00 & 78.51 & +24.51 \\
M02 & 57.00 & 66.18 & +9.18 \\
M03 & 64.00 & 78.95 & +14.95 \\
M04 & 65.00 & 69.54 & +4.54 \\
M05 & 68.00 & 81.52 & +13.52 \\
M06 & 69.00 & 76.87 & +7.87 \\
M07 & 71.00 & 85.46 & +14.46 \\
M08 & 71.00 & 67.72 & -3.28 \\
M09 & 74.00 & 83.46 & +9.46 \\
M10 & 77.00 & 66.92 & -10.08 \\
M11 & 77.00 & 74.96 & -2.04 \\
M12 & 78.00 & 77.36 & -0.64 \\
M13 & 80.00 & 73.16 & -6.84 \\
M14 & 81.00 & 75.74 & -5.26 \\
M15 & 81.00 & 86.15 & +5.15 \\
M16 & 81.00 & 81.69 & +0.69 \\
M17 & 82.00 & 77.46 & -4.54 \\
M18 & 83.00 & 73.44 & -9.56 \\
M19 & 83.00 & 80.23 & -2.77 \\
M20 & 84.00 & 81.00 & -3.00 \\
M21 & 85.00 & 78.23 & -6.77 \\
M22 & 86.00 & 81.29 & -4.71 \\
M23 & 88.00 & 79.60 & -8.40 \\
M24 & 91.00 & 84.78 & -6.22 \\
M25 & 91.00 & 82.64 & -8.36 \\
M26 & 95.00 & 88.86 & -6.14 \\
M27 & 97.00 & 91.70 & -5.30 \\
M28 & 98.00 & 87.58 & -10.42 \\
\hline Mean & 78.96 & 78.96 & $7.45 *$ \\
S.D. & 11.20 & 6.51 & \\
\hline. Mea & & & \\
\hline
\end{tabular}

* : Mean difference was calculated by the absolute value.

to KERLEY (1965) and THOMPSON's (1979) left femur and nonpathological left femur of female samples (Table 1). This results might have been caused by the small sample size, higher mean age of the sample, and less age range of the sample. THOMPSON (1979) calculated the regression formula separately for nonpathological and pathological conditions. Although, the samples' primary cause of death is known (Tables 9,10$)$, the secondary cause of death was unknown in this study. It is known that diabetes mellitus would
Table 8. Comparisons of known age and histologically estimated age for females

\begin{tabular}{|c|c|c|c|}
\hline IDNO & $\begin{array}{c}\text { Known age } \\
\text { (years) }\end{array}$ & $\begin{array}{l}\text { Estimated age } \\
\text { (years) }\end{array}$ & $\begin{array}{c}\text { Difference } \\
\text { (years) }\end{array}$ \\
\hline F01 & 43.00 & 61.81 & +18.81 \\
\hline F02 & 43.00 & 56.65 & +13.65 \\
\hline F03 & 49.00 & 56.07 & +7.07 \\
\hline F04 & 65.00 & 68.96 & +3.96 \\
\hline F05 & 66.00 & 77.50 & +11.50 \\
\hline F06 & 66.00 & 60.27 & -5.73 \\
\hline F07 & 69.00 & 88.64 & +19.64 \\
\hline F08 & 73.00 & 56.48 & -16.52 \\
\hline F09 & 73.00 & 70.95 & -2.05 \\
\hline F10 & 74.00 & 75.03 & +1.03 \\
\hline F11 & 75.00 & 81.94 & +6.94 \\
\hline $\mathrm{F} 12$ & 80.00 & 78.12 & -1.88 \\
\hline F13 & 82.00 & 72.17 & -9.83 \\
\hline $\mathrm{F} 14$ & 82.00 & 74.11 & -7.89 \\
\hline F15 & 82.00 & 84.61 & +2.61 \\
\hline F16 & 83.00 & 81.61 & -1.39 \\
\hline $\mathrm{F} 17$ & 84.00 & 82.75 & -1.25 \\
\hline F18 & 85.00 & 83.40 & -1.60 \\
\hline F19 & 85.00 & 85.28 & +0.28 \\
\hline F20 & 88.00 & 74.16 & -13.84 \\
\hline F21 & 89.00 & 90.24 & +1.24 \\
\hline $\mathrm{F} 22$ & 93.00 & 91.74 & -1.26 \\
\hline F23 & 94.00 & 77.30 & -16.70 \\
\hline $\mathrm{F} 24$ & 94.00 & 87.21 & -6.79 \\
\hline Mean & 75.71 & 75.71 & $7.23^{*}$ \\
\hline S.D. & 14.67 & 10.97 & \\
\hline
\end{tabular}

affect the bone remodeling in reducing the secondary osteon formation rates (KELIN and FROST, 1964). These unknown secondary cause might have affected the accuracy of my study. Other factors that might have affected cortical bone remodeling include, hip joint fracture, fracture of femur or tibia, the degree of physical exercise, length of time persons were confined to bedrest, medications administered, parity, duration of illness prior to death (THOMPSON, 1979), diet and length of daylight which may influence activity pattern (THOMPSON and GUNNESS-HEY, 1981) nutritional stress (GARN, 1970), and diet (RICHMAN et al., 1979). 
Table 9. Subject description for males

\begin{tabular}{|c|c|c|}
\hline IDNO & Age (years) & Primary cause of death \\
\hline M01 & 54 & Pulmonary tubercurosis \\
\hline M02 & 57 & Respiratory failure \\
\hline M03 & 64 & Cerebral infraction \\
\hline M04 & 65 & Rectal cancer \\
\hline M05 & 68 & Pneumonia \\
\hline M06 & 69 & Cerebral thrombosis \\
\hline M07 & 71 & Gastric cancer \\
\hline M08 & 71 & Senile weakness \\
\hline M09 & 74 & Pulmonary tubercurosis \\
\hline M10 & 77 & Hepatic cancer \\
\hline M11 & 77 & Suicide \\
\hline M12 & 78 & Gastric cancer \\
\hline M13 & 80 & Hypertention, Heart failure \\
\hline M14 & 81 & Gastric cancer, Hepatic cancer \\
\hline M15 & 81 & Hepatic cancer \\
\hline M16 & 81 & Heart failure \\
\hline M17 & 82 & Heart failure \\
\hline M18 & 83 & Heart failure \\
\hline M19 & 83 & Uremia \\
\hline M20 & 84 & Bronchial pneumonia \\
\hline M21 & 85 & Renal failure \\
\hline M22 & 86 & Heart failure \\
\hline M23 & 88 & Gastric cancer \\
\hline M24 & 91 & Heart failure \\
\hline M25 & 91 & Senile weakness \\
\hline M26 & 95 & Heart failure \\
\hline M27 & 97 & Senile weakness \\
\hline $\mathrm{M} 28$ & 98 & Senile weakness \\
\hline
\end{tabular}

More detailed study would be necessary in future. However, this technique is useful in the field of physical anthropology and forensic anthropology in four points: firstly, this technique requires less time for examination than other methods; secondly, the damage to the skeletal material is minimized; thirdly, this technique would enable the estimation of age at death from single long bones; and fourthly, this would extend the age estimation to the individuals over 50 years.

\section{Acknowledgements}

I am grateful to the individuals as follows. Prof. W. S. LAUGHLIN, Dr. A. B. HARPER, and
Table 10. Subject description for females

\begin{tabular}{lcl}
\hline IDNO & Age (years) & Primary cause of death \\
\hline F01 & 43 & Acute heart failure \\
F02 & 43 & Ovary cancer \\
F03 & 49 & Heart valvular disease \\
F04 & 65 & Suicide \\
F05 & 66 & Rectal cancer \\
F06 & 66 & Sigmoid colon cancer \\
F07 & 69 & Mammary cancer \\
F08 & 73 & Cerebral hemorrhage \\
F09 & 73 & Pancreatic cancer \\
F10 & 74 & Drowned \\
F11 & 75 & Suicide \\
F12 & 80 & Heart failure \\
F13 & 82 & Acute heart failure \\
F14 & 82 & Uterine cancer \\
F15 & 82 & Gastric cancer \\
F16 & 83 & Pneumonia \\
F17 & 84 & Pneumonia \\
F18 & 85 & Senile weakness \\
F19 & 85 & Hepatic cancer \\
F20 & 88 & Colon cancer \\
F21 & 89 & Senile weakness \\
F22 & 93 & Senile weakness \\
F23 & 94 & Heart failure \\
F24 & 94 & Acute heart failure \\
\hline
\end{tabular}

Ms. S. B. LAUGHLIN of Laboratory of Biological Anthropology, Univ. of Connecticut provided me the laboratory space, equipment, and useful suggestions. Prof. G. A. HARRISON, Dr. V. REYNOLDS, Dr. A. J. BOYCE, and Dr. G. BRUSH of Dept. of Biological Anthropology, Univ. of Oxford gave me useful comments when I wrote my M.Sc. thesis. Prof. A. YAMAUCHI of Dept. of Anatomy, Faculty of Medicine, Univ. of Tokyo and Prof. A. ICHIKAWA of Dept. of Anatomy, School of Medicine, Yokohama City Univ. kindly permitted me to collect the bone samples under their care. Dr. D. D. THOMPSON of Dept. of Bone Biology and Osteoporosis, Merck Sharp and Dohme Research Laboratories, Prof. E. J. CLEGG of Dept. of Anatomy, School of Medicine, Univ. of Aberdeen, Dr. D. H. UBELAKER of Dept. of 
Anthropology, Smithsonian Institution, Dr. H. T. UYTTERShauT of Dept. of Anatomy and Embryology, Univ. of Leiden, Prof. B. VANDERMEERSCH of Laboratoire d'Anthropologie, Université de Bordeaux I, Prof. emeritus H. SUZUKI and Prof. B. ENDO of Dept. of Anthropology, Faculty of Science, Univ. of Tokyo gave me useful comments. Dr. $\mathrm{H}$. SAKURA and Dr. H. BABA of Dept. of Anthropology, National Science Museum, Tokyo, read the manuscript and gave me useful comments. This study was partially supported by Sasakawa Fund, Oriental Institute, Univ. of Oxford and Linacre Trust Fund, Linacre College, Univ. of Oxford.

\section{抄録}

大腿骨骨組織による死亡年齢推定

一現代日本人への THOMPSONのコア・テクニックの応 用一

楢 崎 修一郎

近年，骨組織による死亡年齢推定法が盛んになり， いくつかの方法が提唱されている（AHLQVIST and DAMSTEN, 1969; KeRLEY, 1965; Singh and GUNBERG, 1970; THOMPSON, 1979) が, THOMPSONによる “コア . テクニック”は，資料となる人骨の損傷を最小限に抑 えるといら利点がある，この方法は，高速ドリルを使 用して人骨より直径 $4 \mathrm{~mm}$ のコアを取り出し，その骨組 織の加齢変化を指標として死亡年齢を推定するもので ある。THOMPSONは，この方法を死亡年齢・性別の 判っている解剖学実習用遺体・検死遺体に応用して, 重回帰分析を行い, 白人用の重回帰推定式を算出し た. THOMPSONの研究では, 左右の上腕骨・尺骨・大 腿骨・脛骨が推定に使われたが，大腿骨が最も良く推 定できる部位であることが判明した。そこで，本研究 では日本人の解剖学実習用遺体の左・大腿骨からコア を取り出し死亡年齡推定を行った。

資料は, 東京大学医学部解剖学教室の解剖学実習用 遺体22例（男性11例，女性11例），及び横浜市立大学医 学部解剖学教室の解剖学実習用遺体30例（男性17例, 女性13例）の計52例である.男性28例の死亡年齢は，
54歳から98歳, 平均78.96歳であり, 女性 24 例の死亡 年齢は, 43歳から94歳, 平均75.71歳である.

THOMPSONは，19の骨組織を死亡年齢推定の変量と して用いたが, 本研究では8つの変量, 骨緻密質( ア）の厚さ, コアの重量, 第二次オステオンの数, 第 二次オステォンの平均面積, 第二次オステオンの面積 の標準偏差, 第二次オステオンの平均周辺長, 第二次 オステオンの周辺長の標準偏差，一定面積に占める第 二次オステオンの総面積を用いた。 そのらち, 第二次 オステオンの面積の標準偏差と第二次オステオンの周 辺長の標準偏差は, 本研究で新たに導入された。これ らの変量により重回帰分析を行い, 日本人用の重回㷌 推定式を算出し，男性で重相関保数 0.581 , 標準誤差 9.28 , 女性で重相関係数 0.748 , 標準誤差 9.95 といら 結果を得た。

この結果は，信頼性が高いとは言えないが，死亡年 齢が50歳以上で; しかも大腿骨しか存在しない場合で も死亡年齢推定が可能であう，また骨資料の損傷を従 来の方法よりも最小にとどめるといら点で有効である 5.

\section{References}

AHLQVIST, J. and D. DAMSTEN, 1969: A modification of KERLEY's method for the microscopic determination of age in human bone. J. Forensic Sci., 14: 205-212.

ARNOLD, J.S., M.H. BARTLEY, S.A. TONT and D.P. JENKINS, 1966: Skeletal changes in aging and disease. Clin. Orthop., 149: 17-38.

BOUVIER, M. and D.H. UBELAKER, 1977: A comparison of two methods for the microscopic determination of age at death. Am. J. Phys. Anthropol., 46: 391-394.

CURREY, J.D., 1964: Some effects of ageing in human Haversian systems. J. Anat., 98: 69-75.

ENLOW, D.H., 1963: Principles of Bone Remodeling. C.C. Thomas, Springfield, I11.

Frost, H.M., 1963: Bone Remodeling Dynamics. C.C. Thomas, Springfield, I11.

GARN, S.M. 1970: The Earlier Gain and the Later Loss of Cortical Bone. C.C. Thomas, Springfield, I11.

JOWSEY, J., 1960: Age changes in human bone. Clin. Orthop., 17: 210-217.

KELIN, M. and H.M. FROST, 1964: The numbers of bone resorption and formation foci in rib. Henry Ford Hosp. Med. Bull., 12: 527-536.

KERLEY, E.R., 1965: The microscopic determination of age in human bone. Am. J. Phys. Anthropol., 23: 149-163. 
KERLEY, E.R., 1969: Age determination of bone fragments. J. Forensic Sci., 14: 59-67.

KERLEY, E.R., 1970: Estimation of skeletal age: after about age 30. In: T.D. STEWART (ed.), Personal Identification in Mass Disasters. Smithsonian Institution, Washington, D.C., pp. 57-70.

KERLEY, E.R. and D.H. UBELAKER, 1978: Revisions in the microscopic method of estimating age at death in human cortical bone. Am. J. Phys. Anthropol., 49: $545-546$.

MAZESS, R.B., 1982: On aging bone loss. Clin. Orthop. Rel. Res., 165: 239-252.

RICHMAN, E.A., D.J. ORTNER and F.P. SCHULTERELLIS, 1979: Differences in intracortical bone remodeling in three aboriginal American populations: Possible dietary factors. Calc. Tiss. Int., 28: 209-214.

SINGH, I.J. and D.L. GUNBERG, 1970: Estimation of age at death in human males from quantitative histology of bone fragments. Am. J. Phys. Anthropol., 33: 373-381.

STOUT, S.D. and S.J. GEHLERT, 1982: Effects of field size when using KERLEY's histological method for determination of age at death. Am. J. Phys. Anthropol., 58: 123-125.

THOMPSON, D.D., 1979: The core technique in the determination of age at death in skeletons. J. Forensic Sci., 24: 902-915.

THOMPSON, D.D., 1981: Microscopic determination of age at death in an autopsy series. J. Forensic Sci., 26: 470-475.

THOMPSON, D.D. and K.S. COWEN, 1984: Age at death and bone biology of the Barrow mummies. Arctic Anthrop., 21: 83-88.

THOMPSON, D.D. and C.A. GALVIN, 1983: Estimation of age at death by tibial osteon remodeling in an autopsy series. Forensic Sci. Int., 22: 203-211.

THOMPSON, D.D. and M. GUNNESS-HEY, 1981: Bone mineral-osteon analysis of Yupik-Inupiaq skeletons. Am. J. Phys. Anthropol., 55: 1-7.

THOMPSON, D.D., A.B. HARPER, W.S. LAUGHLIN, and J.B. JØRGENSEN, 1982: Bone loss in Eskimos. In: B. HARVALD and J.P. HART-HANSEN (eds.) Circumpolar Health 1981. Nordic Council for Arctic
Medical Research, Report Series 33, Stougaard Jensen, Copenhagen, pp. 327-330.

THOMPSON, D.D. and S.B. LAUGHLIN, 1985: Histological estimation of age at death of a female mummy from Chihuahua, Mexico. In: R.A. TYSON and V. ELERICK (eds.), Two Mummies from Chihuahua, Mexico. San Diego Museum Papers No. 19, pp. 47-52.

THOMPSON, D.D., S.B. LAUGHLIN, W.S. LAUGHLIN, and C.F. MERBS, 1982-1984: Bone core analysis and vertebral pathologies in Sadlermiut Eskimo skeletons. OSSA, 9/11: 189-197.

ThOMPSON, D.D., E.M. SAlter, and W.S. LAUGHLIN, 1981: Bone core analysis of Baffin Island skeletons. Arctic Anthrop., 18: 87-96.

THOMPSON, D.D. and E. TRINKAUS, 1980: Age determination for the Shanidar 3 Neanderthal. Science, 212: 575-577.

TRINKAUS, E. and D.D. THOMPSON, 1987: Femoral diaphyseal histomorphometric age determinations for the Shanidar 3, 4, 5, and 6 Neandertals and Neandertal longevity. Am. J. Phys. Anthropol., 72: 123-129.

UBELAKER, D.H., 1974: Reconstruction of demographic profiles from ossuary skeletal samples. Smithsonian Contributions to Anthropology, No. 18, Washington, D. C.

UBELAKER, D.H., 1978: Microscopic analysis of archaeological bone. In; D. MORSE (ed.), Ancient Disease in the Midwest. Illinois State Museum Reports of Investigations, No. 15, pp. 66-72.

UBELAKER, D.H., 1986: Estimation of age at death from histology of human bone. In; M.R. ZIMMERMAN and J.L. ANGEL (eds.), Dating and Age Determination of Biological Materials. Croom Helm, London, pp. 240-247.

UYTTERSCHAUT, H.T., 1985: Determination of skeletal age by histological methods. Z. Morph. Anthrop., 75: 331-340.

ZHU, F., 1983: Preliminary study of determination of bone age by microscopic method. Acta Anthropologica Sinica, 2: 142-151. (In Chinese with English summary)
楢 崎 修一郎

Shuichiro NARASAKI
東京大学理学部人類学教室

干113 東京都文京区本郷7-3-1

Department of Anthropology, Faculty of Science, The University of Tokyo

7-3-1 Hongo, Bunkyo-ku, Tokyo 113, Japan 